\title{
Preparation and Evaluation of the Effect of Acetyl Hexapeptide-8 Ampoule for Scalp Treatment
}

\author{
Hae-Won Jo ${ }^{1}$, Kyung-Hee Lee ${ }^{2}$, Jeong-Hee Kim ${ }^{3 *}$ \\ ${ }^{1}$ Department of Beauty Design, Wonkwang University, Iksan-si, Jeollabuk-do, Korea \\ ${ }^{2}$ Department of Makeup Design, Daekyeung University, Gyeongsan-si, Gyeongsangbuk-do, Korea \\ ${ }^{3}$ Institute of W-antiaging, Wonkwang University, Iksan-si, Jeollabuk-do, Korea
}

\author{
*Corresponding author: Jeong-Hee Kim, \\ Institute of W-antiaging, Wonkwang University, \\ 460 lksan-daero, Iksan-si, Jeollabuk-do \\ 54538, Korea \\ Tel.: +82635806898 \\ Fax: +82638507301 \\ Email: jh@wku.ac.kr
}

Hae-Won Jo and Kyung-Hee Lee contributed equally to this work.

Received August 8, 2021

Revised August 11, 2021

Accepted September 3, 2021

Published September 30, 2021

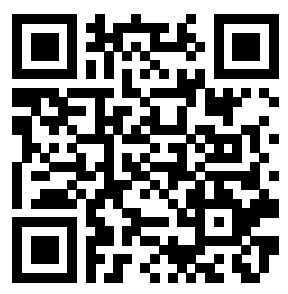

\begin{abstract}
Purpose: The topical application of scalp-care cosmetics, infused with functional ingredients, can offer an optimal cosmetic approach to prevent problems associated with aging. In terms of the development of anti-aging cosmetics, we studied the use of acetyl hexapeptide-8 (AH-8) for improving elasticity of the scalp. Methods: Ampoules containing 3\% and $5 \%$ concentrations of $\mathrm{AH}-8$ as an active ingredient were prepared and their safety and efficacy were evaluated. HaCaT cells were used to evaluate the safety of $\mathrm{AH}-8$ ampoules by measurement of in vitro cytotoxicity. In in vivo experiments, we tested the $\mathrm{AH}-8$ ampoules by cumulative irritation test (CIT) on healthy adults, 20-50 years of age. Relative expressions of superoxide dismutase 2 (SOD2), forkhead box 01 (FOXO1), actinin alpha 1 (ACTN1), collagen type XVII alpha 1 chain (COL17A1), and integrin subunit beta 4 (ITGB4) were assessed using quantitative real-time PCR (Q-PCR). Results: AH-8 ampoules showed significant cytotoxicity to HaCaT cells in a dose-dependent manner. CIT assessment in 30 adults revealed no skin reactions to both $3 \%$ and $5 \% \mathrm{AH}-8$ ampoules. After treatment of $\mathrm{HaCaT}$ cells with the AH-8 ampoules, mRNA levels of SOD2 and FOXO1, which are directly implicated as antioxidant factors, were increased. Of the factors that improve elasticity, ACTN1 mRNA levels had the greatest increase when treated with the $5 \%$ AH-8 ampoules $(1.75 \mu \mathrm{g} / \mathrm{mL})$. Also, the $\mathrm{AH}-8$ ampoules increased mRNA levels of COL17A1, and ITGB4 in HaCaT cells. Conclusions: In this study, we proved that 3\% and $5 \% \mathrm{AH}-8$ ampoules are safe for use as a scalp-care cosmetic. $\mathrm{AH}-8$ ampoule had efficacy in anti-aging and improving elasticity of the scalp. This comprehensive test showed that $\mathrm{AH}-8$ can be developed as a cosmetic for anti-aging and improvement of scalp elasticity.
\end{abstract}

Keywords: Acetyl hexapeptide-8, Elasticity, Anti-aging, Scalp care, Ampoule

\section{Introduction}

건강한 모발 및 두피를 유지하기 위해 효능성분을 포함하는 두피 케어 화장품 시장은 증가 추세에 있다. 중소 벤처기업부의 발표에 따 르면 세계시장에서 두피 화장품의 규모는 2020년에는 약 595억 달러 에 달할 것으로 예상하며, 국내시장에서는 약 9,800 억 원에 미칠 것으 로 전망하였으며 앞으로 지속적으로 성장할 것으로 예측하였다.

최근 소비자의 화장품 제품 선택 요인은 과거 브랜드 인지도에서 목적성, 기능성으로 변화되고 있으며 이에 따라 미백, 보습, 자외선 차
단 및 흡수, 유해산소 제거, 콜라겐 합성, 피부 주름 방지 등 다양한 효 능의 화장품이 개발되고 있다. 특히 피부과학과 화학공학의 결합에 기 초하는 기능성 화장품 시장은 꾸준한 상승세를 이어갈 것으로 전망되 고 있다(Jang \& Lee, 2021). 따라서 두피관리 화장품 또한 탄력, 보습 등의 효능 원료 적용과 지루성 두피, 비듬 개선 등의 목적성 제품개발 이 예측된다.

두피관리에 관한 선행 연구를 살펴보면 주로는 천연 추출물을 이용 한 두피관리 제품을 사용하였을 때 두피가 개선되는 효능에 관련한 다 수의 연구가 보고되었고(Lee et al., 2014; Lee \& Kim, 2015), 두피 
마사지를 적용하였을 때 모발의 건강이 개선되는 효과를 보고하고 있 다(Kim \& Kim, 2015). 두피관리에 대한 선행연구는 2001년 이후 지 속해서 보고되고 있으나 네틀추출물, 산삼배양근, 천일염 청대 등의 천연 소재를 활용한 연구가 주로 보고되고 있으며 최근 주목받고 있는 효능원료에 대한 연구는 아직까지 미흡하다. 즉, 현재까지 보고된 국 내의 두피관리 선행연구의 한계점은 주로 천연추출물 적용과 마사지 효과에 국한되어 있으며, 일부는 유사 연구가 반복되고 있는 것이다.

최근 화장품 소재로서 주요한 화두는 경피 흡수와 효능이다. 특히 펩타이드는 피부 투과성이 우수하여 효능 원료로서 개발 및 활용이 증 가추세에 있다. 이 중 아세틸 헥사펩타이드(acetyl hexapetide, $\mathrm{AH}$ )는 보톡스와 유사한 원리로 주름 개선 효능을 가지면서 보톡스 보다 안전 한 생리 활성 펩타이드로 주목받고 있다(Moh et al., 2011; BlanesMira et al., 2002; Hoppel et al., 2015; Lungu et al., 2013). 아세 틸 헥사펩타이드는 진통성 화학물질인 엔케팔린(enkephalins)이 표정 근에 보톡스처럼 작용하여 신경전달물질인 아세틸콜린(acetylcholine) 의 방출을 억제함으로써 근육을 긴장시키는 작용을 한다(Giacomoni, 2008; Zhang \& Falla, 2009). 특히 아세틸 헥사펩타이드-8 (acetyl hexapeptide-8, $\mathrm{AH}-8)$ 을 안면 주름에 적용하여 개선 효과를 보고한 연구는 다수가 보고되었으며(Blanes-Mira et al., 2002; Wisniewski et al., 2014), 눈꺼풀연축, 안검연축, 안검경련. 안륜근의 강직성 경련 과 같은 얼굴 떨림 증상에도 적용하여 코스메슈티컬로서 botulinum toxin 테라피를 대체할 수 있는 탐색적 연구가 보고 되고 있다(Lungu et al., 2013).

두피는 다른 부위의 피부보다 모발과 피지선이 풍부하게 존재하기 때문에 진피층과 피하지방층이 상대적으로 두껍다. 이러한 해부학적
차이로 인해 두피에 사용하는 화장품이 두피를 적절하게 침투하기는 어렵다. 효과적으로 두피를 통과할 수 있으며 탄력개선 효과가 있는 두피용 펩타이드 화장품을 개발한다면 확장된 개념의 항노화 두피용 화장품이 될 수 있다. 아직까지 $\mathrm{AH}-8$ 을 두피관리 화장품 원료로 사 용한 보고는 거의 없다. 피부 탄력 개선 효과가 $\mathrm{AH}-8$ 에서 관찰되며 경피 흡수 또한 우수한 물질로 알려져 있기 때문에 두피관리용 화장품 으로 개발하여 그 효능을 평가하였다.

\section{Methods}

\section{Material and preparation}

두피관리용 앰플 제조에 사용한 acetyl hexapeptide-8 (AH-8)은 비드테크 (DermaPepTM A610; Beadech, Korea)에서 구입하여 사용 하였다(Figure 1).

탄력 개선 효능을 목적으로 하는 두피관리용 화장품을 제조하기 위 해 $\mathrm{AH}-8$ 을 active 원료로 하고 성분의 흡수성이 우수한 앰플 제형으 로 화장품을 제조하였다 (Table 1). 제조 방법은 정제수, 점증제 등의 A 상(phase)의 원료를 계량하여 $\operatorname{Homomixer}^{\circledR}(\mathrm{HM}-\mathrm{U} 1.0$; JPL Co, Korea)로 $50^{\circ} \mathrm{C}, 10 \mathrm{~min}$ 조건으로 혼합하였다. B상은 보습제와 용 제에 해당하는 원료를 계량하여 $\operatorname{Homomixer}^{\circledR}(\mathrm{HM}-\mathrm{U} 1.0)$ 로 $5 \mathrm{~min}$ 간 혼합하였다. 항염증 등에 효과가 있는 천연 추출물 원료 Camellia sinensis leaf extract와 Ginkgo biloba leaf extract를 Homomixer ${ }^{\circledR}$ 로 $10 \mathrm{~min}$ 간 혼합하였다. 마지막으로 경피 흡수가 우수하며 항산화

Table 1. Ingredients of prepared ampoules

(Unit: g)

\begin{tabular}{|c|c|c|c|c|}
\hline Phase & Ingredient & Control & $3 \% \mathrm{AH}-8$ ampoule & 5\% AH-8 ampoule \\
\hline \multirow{7}{*}{ A } & Water & 88.44 & 85.44 & 83.44 \\
\hline & Disodium EDTA & 0.02 & 0.02 & 0.02 \\
\hline & Panthenol & 0.02 & 0.02 & 0.02 \\
\hline & Citric acid & 0.02 & 0.02 & 0.02 \\
\hline & Sodium citrate & 0.08 & 0.08 & 0.08 \\
\hline & Caffeine & 1.00 & 1.00 & 1.00 \\
\hline & Adenosine & 0.04 & 0.04 & 0.04 \\
\hline \multirow{2}{*}{ B } & Butylene glycol & 1.00 & 1.00 & 1.00 \\
\hline & Glycerin & 2.50 & 2.50 & 2.50 \\
\hline \multirow{2}{*}{ C } & Camellia sinensis leaf extract & 2.50 & 2.50 & 2.00 \\
\hline & Ginkgo biloba leaf extract & 2.00 & 2.00 & 4.00 \\
\hline \multirow{5}{*}{ D } & Alcohol denat. & 4.00 & 4.00 & 4.00 \\
\hline & 1-2 Hexanediol & 0.20 & 0.20 & 0.20 \\
\hline & Fragrance & 0.03 & 0.03 & 0.03 \\
\hline & PEG-60 hydrogenated castor oil & 0.15 & 0.15 & 0.15 \\
\hline & Phenoxyethanol & 0.30 & 0.30 & 0.30 \\
\hline $\mathrm{E}$ & Acetyl hexapeptide-8 & & 3.00 & 5.00 \\
\hline
\end{tabular}


<smiles>CSCCC(NC(=O)C(CCC(=O)O)NC(=O)C(CCC(=O)O)NC(C)=O)C(=O)NC(CCC(N)=O)C(=O)NC(CCCNC(=N)N)C(=O)N[C@@H](CCCNC(=N)N)C(N)=O</smiles>

Figure 1. Chemical formula of acetyl hexapeptide-8.

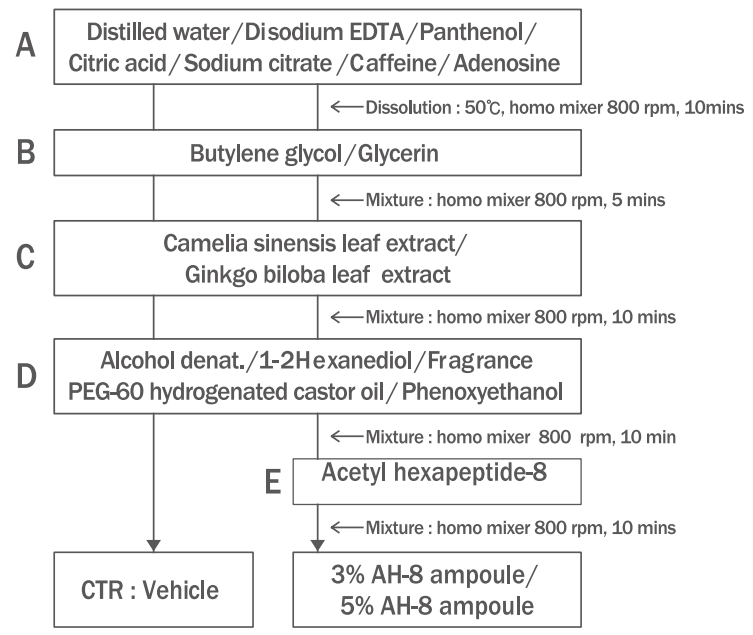

Figure 2. The manufacturing process of ampoules.

및 탄력개선을 위한active 원료인 AH-8을 포함한 D 원료를 계량하여 $\operatorname{Homomixer}^{\circledR}(\mathrm{HM}-\mathrm{U1}$ 1.0)로 $10 \mathrm{~min}$ 간 혼합하였다. $\mathrm{A}+\mathrm{B}+\mathrm{C}+\mathrm{D}$ 상의 혼합과정을 통해 control에 해당하는 vehicle을 제조하였으며, vehicle (control; CTR)에 active 원료인 $\mathrm{AH}-8$ 을 3\%와 5\%를 각각 최종 혼합 하여 두 개의 앰플 시료를 제조하였다(Figure 2).

\section{MTT-assay}

Keratinocyte (인체각질형성세포, $\mathrm{HaCaT}$ )은 Addex Bio에서 분 양 받았다. $\mathrm{HaCaT}$ 세포주는 10\% fetal bovine serum (FBS; Gibco BRL, USA)이 포함된 Dulbecco's Modified Eagle's Medium (DMEM, Gibco; Thermo Fisher Scientific, USA) 배지에 $1 \%$ 의 penicillinstreptomycin (LONZA, Switzerland)을 첨가하여 $37^{\circ} \mathrm{C}, 5 \% \mathrm{CO}_{2}$ 조 건에서 배양하였다. HS68 세포주는 Iscpve's Modified Dulbecco's Medium (IMDM; Gibco) 배지에 10\% FBS와 1\% penicillinstreptomycin을 첨가하여 $37^{\circ} \mathrm{C}, 5 \% \mathrm{CO}_{2}$ 조건에서 배양하였다. 96 well에 각 well 당 human keratinocyte cell과 human skin fibroblast cell을 $2 \times 10^{5}$ cells $/ \mathrm{mL}$ 로 $37^{\circ} \mathrm{C}, 5 \% \mathrm{CO}_{2}$ 의 조건에서 $24 \mathrm{~h}$ 배양하 였다. 배양 후 시료를 농도 및 시간 별로 세포생존율을 측정하였다. 배양된 세포에 $5 \mathrm{mg} / \mathrm{mL}$ 의 3-(4,5-dimethylthiazol- 2-yl-2,5diphenyl tetrazolium bromide (MTT) 시약을 각 well에 $50 \mu \mathrm{L}$ 씩 첨 가하여 $4 \mathrm{~h}$ 동안 반응시킨 후 상층액을 제거하여 $200 \mu \mathrm{L}$ 의 $\mathrm{DMSO}$ 를 첨가 후 생성된 formazan을 용해시켜 96 well에 well 당 $90 \mu \mathrm{L}$ 씩 옮 겨 Microplate reader (SLT; SLT Lab instruments, Austria)에서 570 $\mathrm{nm}$ 의 파장으로 흡광도를 측정하였다.

\section{Cumulative irritation test}

연구지원자의 구성은 30-40 세에 해당하는 한국 여성 33명을 대상 으로 선정하였다. 선정 기준은 피부 및 두피 부위에 관련 피부질환이 없는 자로 하였다. 제조된 시료의 인체적용시험을 수행하기 위해 원광 대학교 생명윤리위원회(Institution Review Board, IRB) 심사를 실시 하고 연구 수행의 승인을 받았다 (연구승인번호: WKIRB-202104$\mathrm{HR}-023) . \mathrm{RB}$ 승인 후 연구지원자를 대상으로 연구의 목적과 과정을 자세히 설명하였다.

피부적용 안정성 평가를 위해 누적자극시험(cumulative irritation test, CIT)을 시행하였다. 연구의 지원자는 피부 관련 질환이 없는 건 강한 피부를 가진 30-40 세 여성 33명을 대상으로 하였다. 연구 지원 자를 대상으로 연구의 목적과 과정을 자세히 설명하고 2021년 5 월 1 일부터 2021년 5 월 31 일까지 첩포 시험을 수행하였다. 첩포를 적용하 는 부위는 피험자의 척추 기립근을 축으로 양쪽 견갑골 사이로 하였 다. 시험 부위를 70\% 에탄올로 닦은 후 각 시료들을 $25 \mu \mathrm{L}$ 씩IQ ultra patch test units (Chemotechnique diagnostics, Sweden)에 적하하여 고정시켰다. $48 \mathrm{~h}$ 밀폐시킨 후 첩포를 제거하고 $30 \mathrm{~min}$ 후의 피부 반

Table 2. international contact dermatitis research group guideline

\begin{tabular}{lcl}
\hline Positive/Negative & Score & \multicolumn{1}{c}{ Criteria } \\
- & 0 & No irritant reaction (discrete patchy erythema without infiltration) \\
-++ & 0.5 & Doubtful reaction (faint macular, no infiltration, homogenous erythema) \\
+ & 1 & Week positive reaction (erythema, induration, papules) \\
++ & 2 & Strong positive reaction (erythema, induration, papules, discrete vesicles) \\
+++ & 3 & Extreme Positive reaction (coalescing vesicles, bullous or ulcerative reaction) \\
\hline
\end{tabular}


응을 확인하였다. 첩포검사 기간은 일주일에 1 회씩 3 주 동안 실험을 진행하였다. 결과 판독은 국제 접촉 피부염 연구위원회 (International Contact Dermatitis Research Group, ICDRG)의 기준에 따라 홍반 발 생 유무 및 정도를 육안으로 판정하였다(Table 2).

\section{RNA purification and Q-PCR Amplification}

$\mathrm{HaCaT}$ 세포에 $\mathrm{AH}-8$ 앰플 시료를 처치한 후 $24 \mathrm{~h}$ 동안 배양하였 다. 세포로부터 Total RNA 추출은 TRIzol ${ }^{\mathbb{Q}}$ (Thermo Fisher Scientific, $\mathrm{USA}$ )을 사용하였다. Total RNA $1 \mu \mathrm{g}$ 을 $\mathrm{cDNA}$ 로 전환하였다. cDNA $1 \mu \mathrm{L}$, PCR Master Mix (2X Real-Time PCR Maser Mix; $\mathrm{BIOFACT}$, Korea) $5 \mu \mathrm{L}$, primer 각각 $1 \mu \mathrm{L}$ 씩 혼합하였고, $\mathrm{DEPC}-$ treated water $2 \mu \mathrm{L}$ 를 혼합하여 최종 용량은 $10 \mu \mathrm{L}$ 로 하였다. 유전 자 증폭은 측정하고자 하는 유전자에 특이적인 염기서열을 가지고 있는 프라이머(Table 3)로 Step OnePlus Real-Time PCR System (Applied Biosystems, USA)의 매뉴얼에 따라 진행하였다. 중합효소 연쇄반응 조건은 최초 $95^{\circ} \mathrm{C} 10 \mathrm{~min}$ 동안 시행하고 $95^{\circ} \mathrm{C} 15 \mathrm{~s}, 60^{\circ} \mathrm{C}$ $1 \mathrm{~min}$ 으로 총 40 회를 진행하였다. 유전자 전사 발현 정도는 $\mathrm{GAPDH}$ 와의 상대적 수치로 측정하였다. 실험 결과는 $\mathrm{ABI}$ Step OnePlus software $^{\circledR}$ (Applied Biosystems)를 사용하여 분석하였다.

\section{Statistical analysis}

자료 분석은 모두 유의수준 $5 \%$ 에서 검증하였으며, 통계처리는 SPSS for windows version 24.0 program을 사용하였다. 데이터의 기술통계는 평균과 표준편차, 변화 값을 구하였다. 결과의 비교 분석 을 위해 paired t-test를 실시하였다.

\section{Results \& Discussion}

\section{1. $\mathrm{AH}-8$ 앰플의 세포생존율 분석}

$3 \%$ 와 $5 \%$ 의 $\mathrm{AH}-8$ 앰플의 세포독성을 평가하기 위해 $0.5 \mu \mathrm{g} / \mathrm{mL}$,

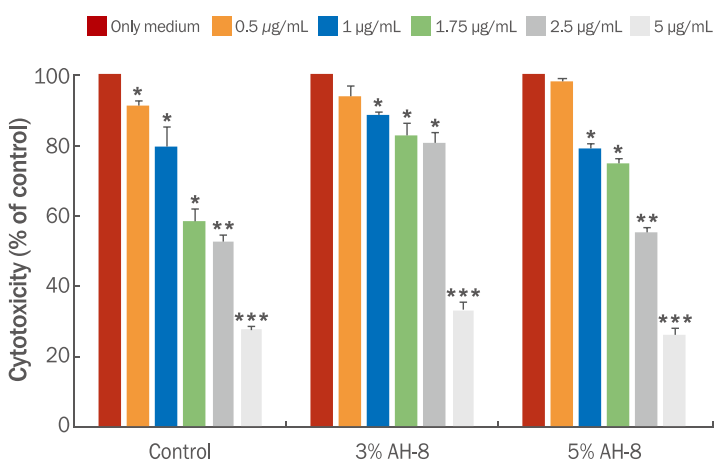

Figure 3. Viability of HaCaT cells exposed to ampoules of various concentrations.

Each value represents the means \pm standard deviation of three replicates. * present compared to only medium condition in each sample. Data analysis was performed using paired t-tests. Statistical significance was found at ${ }^{*} p<0.05,{ }^{* *} p<0.01$, ${ }^{* * *} p<0.001$.

$1 \mu \mathrm{g} / \mathrm{mL}, 1.75 \mu \mathrm{g} / \mathrm{mL}, 2.5 \mu \mathrm{g} / \mathrm{mL}, 5 \mu \mathrm{g} / \mathrm{mL}$ 의 5 개의 농도 별 시 료를 $\mathrm{HaCaT}$ 세포에 처리하여 세포생존율을 측정하였다. Control의 경우 $1.75 \mu \mathrm{g} / \mathrm{mL}$ 농도에서 세포생존율이 79. $28 \%$ 로 측정되었으며 $3 \% \mathrm{AH}-8$ 앰플 시료는 $2.5 \mu \mathrm{g} / \mathrm{mL}$ 까지 농도를 높였을 때 $80,3 \%$ 의 세포생존율을 보였다. $5 \% \mathrm{AH}-8$ 시료에서는 $1.75 \mu \mathrm{g} / \mathrm{mL}$ 의 농도에 서 $74.44 \%$ 의 세포생존율을 확인하였다(Figure 3). $3 \% \mathrm{AH}-8$ 가 함유 된 두피관리용 앰플 시료가 control과 $5 \% \mathrm{AH}-8$ 에 비해 동일 농도에 서 세포생존율이 가장 높게 나타났으며, control에서 가장 낮은 세포 생존율을 보였다. 이상의 결과 $\mathrm{AH}-8$ 은 $\mathrm{HaCaT}$ 세포에 독성 효과가 control에 비해 상대적으로 크지 않음을 알 수 있었다(Figure 3). 동일 농도에서 control이 3\%와 5\%의 $\mathrm{AH}-8$ 앰플 시료보다 세포생존율이 낮게 나타난 이유를 살펴보면 각 시료의 유일한 성분차이인 $\mathrm{AH}-8$ 의 함유 유무가 그 원인으로 작용하였을 것으로 추측된다.

Acetyl hexapeptide는 높은 생리활성 펩타이드로서 화장품 원료

Table 3. Primers used in quantitative real-time PCR amplification

\begin{tabular}{|c|c|c|c|}
\hline Gene symbol & Gene name & Primer & Sequence $\left(5^{\prime} \rightarrow 3^{\prime}\right)$ \\
\hline \multirow{2}{*}{ SOD2 } & \multirow{2}{*}{ Superoxide dismutase 2} & Forward & TCGTGGGTGTCCAAGAACTG \\
\hline & & Reverse & ATGAGCTGAGGGTAGAGCCA \\
\hline \multirow{2}{*}{ FOXO1 } & \multirow{2}{*}{ Forkhead box 01} & Forward & GCTGCATCCATGGACAACAACA \\
\hline & & Reverse & CGAGGGCGAAATGTACTCCAGTT \\
\hline \multirow{2}{*}{ ACTIN1 } & \multirow{2}{*}{ Actinin alpha 1} & Forward & TGAGGAGTGGTTGCTGAATGAG \\
\hline & & Reverse & АACTTCTCTGCCAGGTGGTCC \\
\hline \multirow{2}{*}{ COL17A1 } & \multirow{2}{*}{ Collagen type XVII alpha 1 chain } & Forward & GTGTGGTCCAGCATCAGCGT \\
\hline & & Reverse & CGGCTTGACAGCAATACTTC \\
\hline \multirow{2}{*}{ ITGB4 } & \multirow{2}{*}{ Integrin subunit beta 4} & Forward & GCTTCACACCTATTTCCСTGTC \\
\hline & & Reverse & GACCCAGTCCTCGTCTTCTG \\
\hline
\end{tabular}


A

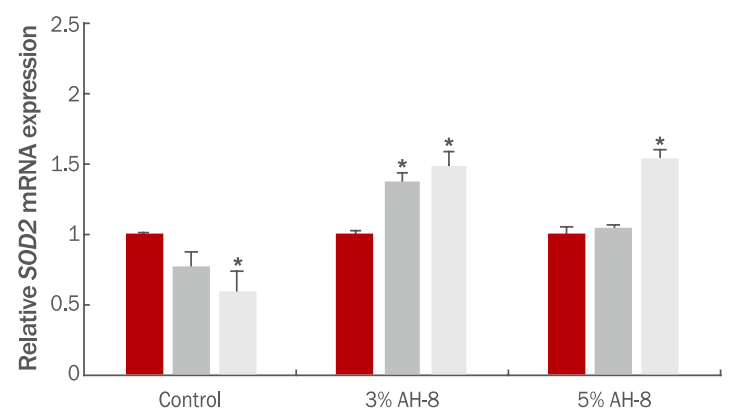

B

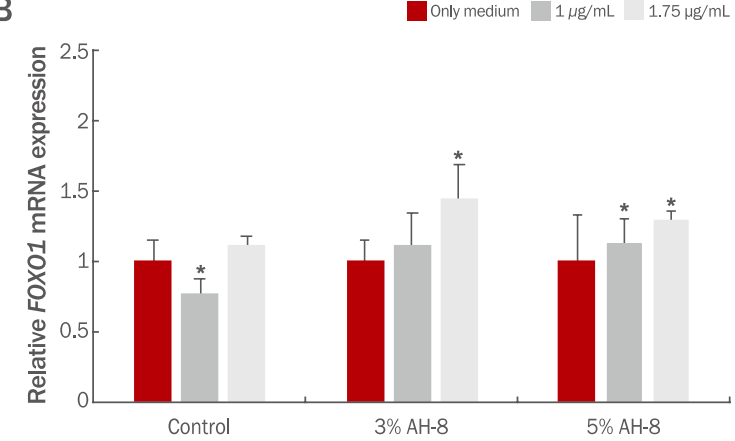

Figure 4. Relative gene expression of (a) SOD2 and (b) FOXO1 in response to acetyl hexapeptide-8 treatment of HaCaT cells after $24 \mathrm{~h}$ of incubation.

*present compared to only medium condition in each sample. Data analysis was performed using paired t-tests. Statistical significance was found at ${ }^{*} p<0.05$.

로서 탄력개선 효능이 탁월한 반면 장기적 노출에서는 잠재적 toxic agent로 추정되고 있다(Kobiela et al., 2018). 결국 뛰어난 효능이 예 상된다 하더라도 장기간 사용에 안전성이 확보되어야 하는 화장품의 안전기준 측면에서 보면 고농도의 AH-8 함유는 앰플은 상대적으로 배제요인이 될 수 있다. 이러한 견해와 같이 두피관리용 앰플 시료의 세포독성 평가 측면에서 $5 \% \mathrm{AH}-8$ 의 고농도 두피관리용 앰플의 적용 보다는 $3 \% \mathrm{AH}-8$ 앰플 시료의 안전성이 우수함을 확인하였다.

\section{AH-8 앰플을 적용한 누적자극시험(CIT) 결과}

두피관리용 $\mathrm{AH}-8$ 앰플 시료의 피부적용에 대한 알레르기 반응 평 가로서 누적자극시험을 실시한 결과, 연구 지원자 30 명 전원이 3 주 간의 3 회 모두 음성(-) 반응이 나타났다(Table 4). 화장품 원료로서 peptide의 활용은 경피 흡수가 우수하며 피부적용에 대한 안전성 확보 가 가장 큰 장점이라 할 수 있다(Kim et al., 2018). 펩타이드에 대한 안전성 평가는 다수가 보고되었고(Kim et al., 2021; Ju et al., 2020), 화장품에서 적용되는 펩타이드의 허용 기준에 따른 사용은 안전하다 는 결과를 보고하였다(Johnson et al., 2018). 이 연구결과에서도 $3 \%$ 와 $5 \% \mathrm{AH}-8$ 앰플 시료를 이용하여 패치테스트 시행한 결과 피부 알 레르기 반응이 나타나지 않아 피부 적용에 대한 안전성을 확인하였다.

\section{AH-8 앰플의 SOD2, FOXO1, ACTN1, COL17A1와 ITGB4 유 전자 발현 변화}

피부의 노화에 관련한 다각적 연구가 지속적으로 진행되고 있으며, 연구의 핵심은 세포의 물리적 민감성(mechnosentitivity)과 중력과 같 은 외부장력을 조절하는 것이다(Piérard et al., 2010). 따라서 두피 탄 력 정도와 항노화에 영향을 미치는 대표적인 인자는 SOD2, FOXO1, $A C T N 1, C O L 17 A 1$ 와 ITGB4로 이들의 $\mathrm{mRNA}$ 의 유전자 발현 변화를 측정하였다.

먼저 FOXO1-SOD2 신호전달체계는 산화 스트레스 조절에 영향 을 미치는 것으로 보고되었다(Zhu et al., 2020). 따라서 $\mathrm{AH}-8$ 앰 플 시료의 항산화능에 대한 평가를 위해 $\mathrm{HaCaT}$ 세포 내에 존재하는 $F O X O 1$ 과 $S O D 2$ 의 mRNA의 유전자 발현 변화를 측정하였다 (Figure 4). $3 \% \mathrm{AH}-8$ 앰플 시료 $1.75 \mu \mathrm{g} / \mathrm{mL}$ 농도에서 FOXO1 mRNA의 발 현이 대조군에 비해 1.45 배 증가하였으나 $5 \% \mathrm{AH}-8$ 앰플 시료의 $1.75 \mu \mathrm{g} / \mathrm{mL}$ 농도에서는 1.29 배로 다소 감소하였다. SOD2 mRNA 발현 변화를 살펴보면, $3 \% \mathrm{AH}-8$ 앰플 시료 $1.75 \mu \mathrm{g} / \mathrm{mL}$ 농도에서 1.5 배로 증가하였고 $5 \% \mathrm{AH}-8$ 앰플 시료의 $1.75 \mu \mathrm{g} / \mathrm{mL}$ 농도에서 1.54 배 증가하였다. $\mathrm{AH}-8$ 의 농도가 증가할수록 $S O D 2 \mathrm{mRNA}$ 발현 량이 농도의존적으로 증가함을 알 수 있었다. 즉, $S O D 2$ 의 발현 증가

Table 4. The results of the patch test for 3 weeks

\begin{tabular}{lcccc}
\hline Sample & Reaction & 1 week & 2 weeks & 3 weeks \\
Control & Positive & 0 & 0 & 0 \\
& Negative & 30 & 30 & 0 \\
$3 \%$ AH-8 ampoule & Positive & 0 & 30 & 30 \\
& Negative & 30 & 0 & 0 \\
$5 \%$ AH-8 ampoule & Positive & 0 & 30 & 30 \\
\hline
\end{tabular}

Negative, no irritant reaction. 


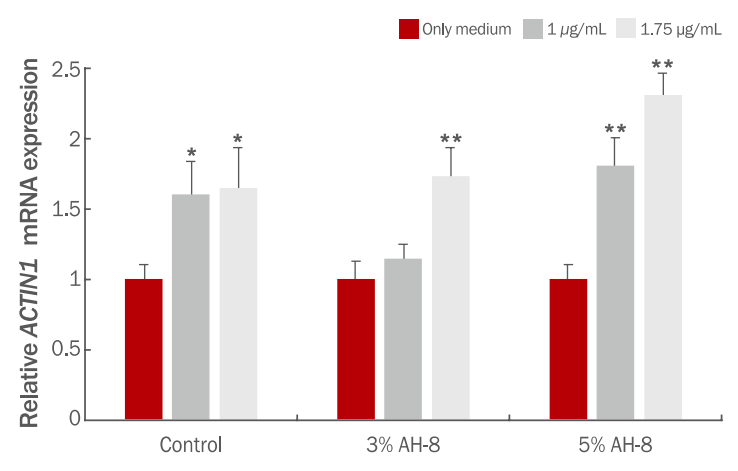

Figure 5. Relative gene expression of ACTIN1 in response to acetyl hexapeptide-8 treatment of HaCaT cells after $24 \mathrm{~h}$ of incubation. * present compared to only medium condition in each sample. Data analysis was performed using paired t-test. Statistical significance was found at ${ }^{*} p<0.05,{ }^{* *} p<0.01$.

는 산화스트레스로부터 세포를 보호하는 $\mathrm{AH}-8$ 앰플 시료의 항산화 효능 있음을 확인하였다.

이전의 연구에서 $\mathrm{HaCaT}$ 세포를 이용하여 acetyl hexapeptide-50 $(\mathrm{AH}-50)$ 의 $\mathrm{FOXO1}$ 와 $\mathrm{SOD} 2 \mathrm{mRNA}$ 의 발현 변화를 측정한 결과, $0.05 \mu \mathrm{g} / \mathrm{mL}$ 경우 $F O X O 1$ 와 $S O D 2 \mathrm{mRNA}$ 발현이 각각 1.2 배, 1.6 배 로 증가하였으나, $5 \mu \mathrm{g} / \mathrm{mL}$ 에서는 $F O X O 1$ 와 $S O D 2 \mathrm{mRNA}$ 발현이 각 각 1.2 배 정도로 $S O D 2 \mathrm{mRNA}$ 발현이 다소 감소한 것으로 보고하였 다(Kobiela et al., 2018). 선행 연구와 같이 펩타이드를 소재로 한 다 양한 효능평가 결과에서 그 효능이 농도의존적으로 나타나기도 하지 만 일정 농도 이상에서는 효능이 다소 감소하는 경향이 보고되고 있 다. 이상의 결과와 같이 이 연구에서도 $F O X O 1 \mathrm{mRNA}$ 의 발현이 $3 \%$ $\mathrm{AH}-8$ 앰플 시료에서는 농도의존적으로 변화하였고 $3 \% \mathrm{AH}-8$ 앰플 시료에서 $F O X O 1 \mathrm{mRNA}$ 의 발현이 가장 높게 나타났으나 이에 비해
$5 \% \mathrm{AH}-8$ 앰플 시료에서는 $F O X O 1 \mathrm{mRNA}$ 의 발현이 다소 저조하게 나타났다.

물리적 자극에 의한 세포 반응과 세포 항상성은 actin cytoskeleton 의 상태에 좌우되며, alpha-actinin-1과 alpha-actinin-4 레벨은 세 포질과 막 분획에 직접적인 관련이 있다(Ogneva, 2013). HaCaT 세포 에 $\mathrm{AH}-8$ 앰플 시료를 처치한 후 $A C T N 1$ 의 $\mathrm{mRNA}$ 의 발현 변화를 모 니터링 하는 것은 $\mathrm{AH}-8$ 앰플이 세포 항상성에 작용하는 변화를 측정 하는 것으로서 두피의 탄력 개선에 직접적인 지표가 될 수 있다. 따라 서 $A C T N 1$ 의 $\mathrm{mRNA}$ 의 발현량을 측정하였다(Figure 5). 그 결과 $3 \%$ $\mathrm{AH}-8$ 앰플 시료 $1.75 \mu \mathrm{g} / \mathrm{mL}$ 농도에서 $A C T I N 1$ 의 mRNA의 발현이 1.8 배 증가하였고 $5 \% \mathrm{AH}-8$ 앰플 시료 $1.75 \mu \mathrm{g} / \mathrm{mL}$ 농도에서는 2.3 배 증가하였다. $\mathrm{HA}-8$ 의 함유량이 증가할수록 $A C T N 1$ 의 mRNA의 발 현이 농도 의존적으로 증가하여 세포의 항상성에 유의한 영향을 주는 것을 확인하였다. 즉 세포의 항상성 조절은 항노화 작용으로서 두피의 탄력 유지 및 개선 효능에 직결될 수 있다.

COL17A1와 ITGB4는 표피세포 유착에 상호연관성이 있다 (Moilanen et al., 2017). 따라서 COL17A1와 ITGB4의 mRNA의 발 현 증가는 피부 탄력을 향상시킨다. COL17A1 mRNA의 발현 변화를 살펴보면(Figure $6 \mathrm{~A}$ ), $3 \% \mathrm{AH}-8$ 앰플 $1 \mu \mathrm{g} / \mathrm{mL}$ 농도에서 대조군에 비해 1.42 배 증가하였다. 그러나 $\mathrm{AH}-8$ 이 함유되지 않은 대조군의 경 우 농도가 증가할수록 $C O L 17 A 1$ 의 mRNA의 발현이 현저하게 감소하 였다. $\mathrm{AH}-8$ 앰플 처리 후 ITGB4의 mRNA의 발현 변화를 살펴보면 (Figure $6 \mathrm{~B}$ ), $3 \% \mathrm{AH}-8$ 앰플 시료에서는 $1 \mu \mathrm{g} / \mathrm{mL}$ 농도에서 1.35 배 증가하였고 $1.75 \mu \mathrm{g} / \mathrm{mL}$ 농도에서 1.52 배 증가하였다. $5 \% \mathrm{AH}-8$ 앰 플 시료에서는 $1 \mu \mathrm{g} / \mathrm{mL}$ 의 농도에서 ITGB4의 mRNA의 발현이 2.29 배로 가장 크게 증가하였다. 이상의 결과는 $\mathrm{AH}-8$ 앰플이 COL17A1 과 ITGB4 $\mathrm{mRNA}$ 의 발현을 증가시켜 궁극적으로 두피탄력을 개선할 수 있을 것으로 사료된다.

B

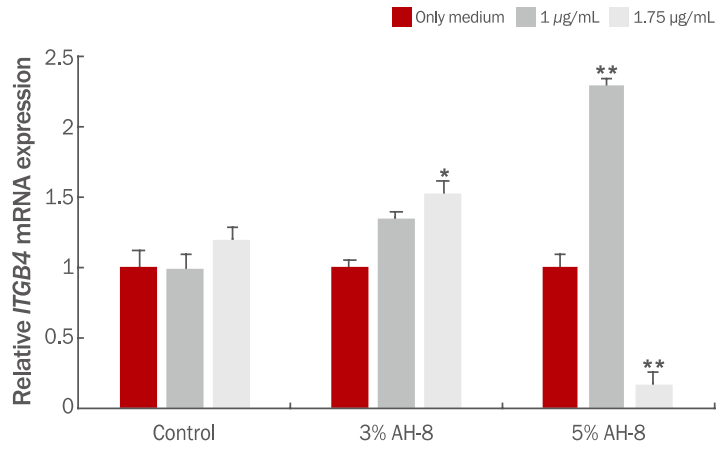

Figure 6. Relative gene expression of (a) COLA17A1 and (b) ITGB4 in response to acetyl hexapeptide-8 treatment of HaCaT cells after $24 \mathrm{~h}$ of incubation.

*present compared to only medium condition in each sample. Data analysis was performed through paired t-tests. Statistical significance was found at ${ }^{*} p<0.05,{ }^{* *} p<0.01$. 


\section{Conclusion}

이 연구에서는 탄력개선 효능이 예측되는 $\mathrm{AH}-8$ 을 이용하여 두피 용 펩타이드 앰플을 제조하고, 이에 대한 안전성 및 효능을 평가하였 다.

$\mathrm{AH}-8$ 앰플 시료의 안전성 평가에서 in vivo 측면의 누적자극시험 결과 $3 \%$ 와 $5 \% \mathrm{AH}-8$ 앰플 모두 피부 사용에 대한 안전성을 확인하 였으나, in vitro 측면의 세포독성 평가 결과에서 $3 \% \mathrm{AH}-8$ 앰플 시 료의 안전성이 가장 우수함을 확인하였다.

$\mathrm{AH}-8$ 앰플의 효능평가로서 항노화 및 두피 탄력 개선에 관련한 대표적인 인자로서 $S O D 2, F O X O 1, A C T N 1, C O L 17 A 1$ 와 ITGB4 $\mathrm{mRNA}$ 발현 변화를 측정하였다. 항노화 인자로서 $\mathrm{SOD} 2, \mathrm{FOXO1}$ $\mathrm{mRNA}$ 발현 변화는 3\%와 $5 \% \mathrm{AH}-8$ 앰플 시료 모두 항산화능 이 있음을 확인하였다. 두피의 탄력개선 연과 인자로서 $A C T N 1$, $C O L 17 A 1$ 와 ITGB4 mRNA 발현 변화를 살펴보면 $A C T N 1$ 의 mRNA 발현은 $\mathrm{AH}-8$ 이 고농도에서 발현이 가장 증폭되어 나타났고, $C O L 17 A 1$ 와 ITGB4 mRNA 발현은 고농도가 아닌 각각 $3 \% \mathrm{AH}-8$ 앰플 $1 \mu \mathrm{g} / \mathrm{mL}$ 농도와 $5 \% \mathrm{AH}-8$ 앰플 $1 \mu \mathrm{g} / \mathrm{mL}$ 농도에서 mRNA 발 현이 가장 크게 증가하였다.

이 연구에서는 두피 흡수가 용이하며 탄력개선 효과가 있는 항노 화 두피용 펩타이드 화장품을 개발하고자 하였다. 결론적으로 $\mathrm{AH}-8$ 을 Active 원료로서 적용하여 두피관리용 화장품을 제조하였을 때 $\mathrm{AH}-8$ 을 $3 \%$ 에서 $5 \%$ 미만 범위의 적정 농도로 적용하여 제조하는 것 이 화장품의 안전성을 확보하고, 항산화 및 탄력 개선 효능을 기대할 수 있는 제형임을 확인하였다.

\section{Author's contribution}

HWJ and KHL contributed equally to this work. HWJ, KHL and JHK designed all experimental investigations. HWJ, KHL and JHK performed experiments and wrote manuscript. JHK oversaw the project.

\section{Author details}

Hae-Won Jo (Gradutae student), Department of Beauty Design, Graduate School of Wonkwang University, 460 Iksan-daera, Iksan-si, Jeallabuk-do 54538, Koera; Kyung-Hee Lee (Professor). Department of Beauty Design, Daekyeung University, 65 Danbuk 1-gil, Jain-myeon, Gyeongsan-si, Gyeongsangbuk-do 38547, Korea; JeongHee Kim (Executive manager and Professor), Institute of W-antiaging, Wonkwang University 460, Iksan-daera, Iksan-si, Jeallabuk-do 54538, Korea.

\section{References}

Blanes-Mira C, Clemente J, Jodas G, Gil A, Fernández-ballester G, Ponsati B, Gutierrez, Pérez-Payá, Ferrer-Montiel A. A synthetic hexapeptide (Argireline) with antiwrinkle activity. International Journal of Cosmetic Science, 24: 303-310, 2002

Giacomoni PU. Advancement in skin aging: The future cosmeceuticals. Clinics in Dermatology, 26: 364-366, 2008.

Hoppel M, Reznicek G, Kahlig H, Kotisch H, Resch GP and Valenta C. Topical delivery of acetyl hexapeptide-8 from different emulsions: influence of emulsion composition and internal structure. European Journal of Pharmaceutical Science, 68:27-35, 2015.

Jang MA, Lee JM. Research on domestic and international industrial trends of functional cosmetics. Journal of the Korean Applied Science and Technology, 38: 618-627, 2021.

Johnson Jr. W, Bergfeld WF, Belsito DV, Hill RA Klaassen CD, Liebler DC, Marks Jr. JG, Shank RC, Slaga, TJ, Snyder PW, Gill $\sqcup$, Heldreth B. Safety assenssment of tripeptide-1, hexapeptide-12, their metal salts and fatty acylderivatives, and palmitoyl tetrapeptide-7 as used in cosmetics. International Journal of Toxicology, 37:91S-102S, 2018.

Ju JH, Kim DH, Park K, Kim NS, Kim JH. Effects of rhEGF and palmitoyl pentapeotide-4 for skin regeneration after glycolic acid peeling. Journal of Korean Society of Cosmetology, 26: 149-153, 2020

Kim GY, Lee SJ, Jeon MJ, Kim BM, Kim GT, Kang SM, Lee KY, Shun EJ, Kim SY, Kim YM. Anti-wrinkle and skin turnover improvement effects of niacinamide-dipeptide convergence. Asian Journal of Beauty and Cosmetology, 16: 234-254, 2018.

Kim NY, Kim JS. A study on effects of Lespedeza cuneata extract on the improvement of scalp conditions in adult Men in Their 30 40s. Asian Journal of Beauty and Cosmetology, 13: 735-742, 2015.

Kim MK, Kim MJ, Kim JW, Kim JH. Control effect of palmitoyl teterapeptide-7 gel to inflammatory responses elicited by PM10. Asian Journal of Beauty and Cosmetology, 19: 2165-174, 2021.

Kobiela T, Milner-Krawcyk M, Pasilkowska-Piwko M, BobeckaWesolowska K, Eris I, Święszkowski W, Dulinska-Molak 
I. The effect of anti-aging peptides on mechanical and biological properties of HaCaT keratinocytes. International Journal of Peptide Research and Therapeutics, 24: 577587, 2018.

Lee MS, Kim MN. The effect about scalp tonic with wild ginsen extraction on scalp and hair. Journal of the Korean Society of Cosmetology, 21: 299-303, 2015.

Lee MS, Joung JS, Park DY. The study about the scalp scaling effect of solar salt and Indigo Pulverata Levis. Asian Journal of Beauty and Cosmetology, 12: 119-125, 2014.

Lungu C, Considine E, Zahir S, Ponsati B, Arrastia S and Hallett M. Pilot study of topical acetyl hexapeptide-8 in the treatment for blepharospasm in patients receiving botulinum toxin therapy. European Journal of Neurology, 20:515-518, 2013.

Moh SH, Jung DH, Kim HS, Cho MJ, Seo HH, Kim SJ. Characteristics and applications of bioactive peptides in skin care. Korean Journal of Biotechnology and Bioengineering, 26: 483-490, 2011.
Ogneva IV. Cell mehanosensitivity: mechanical properties and interaction with gravitational field. BioMed Research International, 2013: 598461-598478, 2013.

Piérard GE, Paquet P, Xhauflaire-Uhoda E, Quatresooz P. Physiological variations during aging. In: Textbook of aging skin. Farage MA, Miller KW, Maibach HI (eds). Springer, Berlin, p45-54, 2010.

Wisniewski JD, Elli DL, Lupo MP. Facial rejuvenation: combining cosmeceuticals with cosmetic procedures. Cuits, 94:122126, 2014.

Zhang L, Falla TJ. Cosmeceuticals and peptides. Clinics in Dermatology, 27:485-494, 2009.

Zhu G, Wu Y, Qiu Y, Tian K, Mi W, Liu X, Chen Y, Jia J, Luo J, Lu L, Qiu J. Hsp70/Bmi-Fox01-SOD signaling pathway contributes to the protective effect of sound conditioning against acute acoustic trauma in a rat model. Neural Plasticity, 3: 1-22, 2020. 


\section{국문초록}

\section{두피관리용 아세틸 헥사펩타이드-8 앰플의 제조 및 평가}

조해원 ${ }^{1}$, 이경희 ${ }^{2}$, 김정희 ${ }^{3 *}$

${ }^{1}$ 원광대학교 뷰티디자인학과, 전라북도 익산시, 한국

${ }^{2}$ 대경대학교 뷰티디자인학과, 경상북도 경산시, 한국

${ }^{3}$ 원광대학교 $\mathrm{W}-$ 안티에이징 연구소, 전라북도 익산시, 한국

목적: 항노화 기능성 화장품의 개발 관점에서 두피의 탄력 개선 효과가 예상되는AH-8을 이용한 항노화 두피관리용 화장품을 제 조하고, 이를 평가하였다. 방법: 이 연구에서는 액티브 원료로서AH-8 (3\% 및 5\%)을 사용하여 두피관리용 앰플을 제조하고, 제조 된 앰플의 안전성과 효능을 평가하였다. In vivo 측면에서 화장품 안전성 평가는 인체각질형성세포(HaCaT)를 사용하여 세포독성 을 평가하였다. In vitro 측면에서 화장품 안전성 평가는 20-50대의 피부질환 및 피부 과민 반응이 없는 성인을 대상으로 피부 적 용에 대한 누적자극시험(cumulative irritation test, CIT)을 실시하였다. 항노화 및 탄력 개선의 효능평가는 HaCaT세포를 이용하여 SOD2, FOXO1, ACTIN1, COL17A1, 및 ITGB4 mRNA 발현 변화를 quantitative real-time PCR (Q-PCR)로 측정하였다. 결과: 인 체적용에 대한 누적자극시험 결과, $3 \%$ 와 $5 \% \mathrm{AH}-8$ 앰플 모두 피부 적용에 대한 안전성을 확인하였다. 세포독성 평가결과에서 $3 \%$ AH-8 앰플 시료의 세포생존율이 가장 높게 나타나 시료 중 세포독성 측면에서의 안전성이 우수함을 확인하였다. 항노화와 탄력개 선에 관련된 SOD2, FOXO1, ACTIN1, COL17A1과 ITGB4 mRNA 발현 변화를 측정한 결과, 3\%와 5\% AH-8 앰플 모두 항노화 인 자인 SOD2, FOXO1 mRNA 발현이 증가하였다. 탄력 개선 관련 인자인 ACTIN1 mRNA 발현은 $\mathrm{AH}-8$ 함량이 가장 높은 고농도(5\% AH-8 앰플 $1.75 \mu \mathrm{g} / \mathrm{mL})$ 에서 발현이 증폭되었고, COL17A1과 ITGB4 mRNA 발현 또한 증가하였다. 결론: $\mathrm{HA}-8$ 을 두피관리용 화장품 앰플로 제조하여 화장품 안전성과 효능을 평가한 결과 화장품으로서 사용에 안전성이 확보되었음을 확인하였다. 또한 효능 측면에서 항노화와 탄력개선 효능을 확인하였다. 이러한 결과를 종합하였을 때 $\mathrm{HA}-8$ 은 항노화 및 두피탄력 개선 효능의 액티브 원 료로서 활용을 기대할 수 있다.

핵심어: 아세틸 헥사펩타이드-8, 탄력, 항노화, 두피관리, 앰플

\section{참고문헌}

김가연, 이승제, 전미지, 김보민, 김근태, 강상문, 이기영, 신은진, 김상용, 김영민. 나이아신 펩타이드 융합체의 항주름 및 피부 턴오버 개선 효과. 아시안뷰티화장품학술지, 16: 234-254, 2018.

김나연, 김주섭. 야관문 추출물을 이용한 30 40대 남성의 두피 개선 효과 연구. 아시안뷰티화장품학술지, 13: 735-742, 2015.

김민경, 김민정, 김주원, 김정희. Palmitoyl Teterapeptide-7 Gel이 PM10에 의해 유발된 염증 반응 제어 효과. 아시안뷰 티화장품학술지, 19: 165-174, 2021.

장민아, 이정민. 기능성 화장품 국내외 산업 동향 연구. 한국응용과학기술학회지, 38: 168-627, 2021.

주지현, 김도현, 박건, 김남산, 김정희. 글릭콜릭산 필링 후 rhEF와 Palmitoyl pentapeptide-4의 피부재생효과. 한국미 용학회지, 26: 149-153, 2020.

이명숙, 김미나. 산삼 배양근이 함유된 두피토닉이 두피와 모발에 미치는 영향. 한국미용학회지, 21: 299-303, 2015.

이미선, 정지선, 박도영. 천일염과 청대를 활용한 두피스케일링 효능에 관한 연구. 아시안뷰티화장품학술지, 12: 119225, 2014.

모상현, 정대현, 김형식, 조문진, 서효현, 김성준. 생리활성펩타이드의 피부미용학적 특성 및 활용. 한국생물공학회지, 26 : 483-490, 2011. 


\section{中文摘要}

\section{乙酰六肽-8精华的制备及头皮治疗效果评价}

趙該元 ${ }^{1}$, 李京喜 ${ }^{2}$, 金柾希 $^{3^{*}}$

${ }^{1}$ 圆光大学美容设计学科, 全罗北道缢山市, 韩国

${ }^{2}$ 大庆大学美容设计学科, 庆尚北道庆山市, 韩国

3 圆光大学 $W$-抗衰老研究所, 全罗北道盆山市, 韩国

目的: 头皮护理化妆品的局部应用，注入功能性成分，可以提供最佳的美容方法，以防止与衰老相关的问题。在 抗衰老化妆品的开发方面，我们研究了乙酰六肽-8（AH-8）对改善头皮弹性的作用。方法：制备含有3\%和5\% 浓度AH-8作为活性成分的精华，并评估其安全性和有效性。通过体外细胞毒性测定，使用HaCaT细胞评估AH-8 精华的安全性。在体内实验中，我们通过累积刺激试验（CIT）对20-50岁的健康成年人进行AH-8精华测试。使 用定量实时PCR (Q-PCR) 评估SOD2、FOXO1、ACTN1、COL17A1和/TGB4的相对表达。结果: AH-8安瓿对 $\mathrm{HaCaT}$ 细胞具有明显的细胞毒性，且呈剂量依赖性。对 30 名成人的CIT评估显示，3\%和 $5 \% \mathrm{AH}-8$ 安瓿均无皮肤 反应。在用 $\mathrm{AH}-8$ 精华处理 $\mathrm{HaCaT}$ 细胞后, SOD2和FOXO1的mRNA水平增加, 它们直接与抗氧化因子有关。在 改善弹性的因素中, 当使用 $5 \% A H-8$ 精华 $(1.75 \mu \mathrm{g} / \mathrm{mL})$ 处理时, ACTN1 mRNA水平的增加幅度最大。此外, $\mathrm{AH}-8$ 精华增加了 $\mathrm{HaCaT}$ 细胞中 COL 17A1和ITGB4的mRNA水平。结论: 在本研究中, 我们证明了 $3 \%$ 和 $5 \% \mathrm{AH}-8$ 精华 作为头皮护理化妆品是安全的。AH-8安瓿具有抗衰老和改善头皮弹性的功效。这项综合试验表明, $\mathrm{AH}-8$ 可 作为抗衰老和改善头皮弹性的化妆品开发。

关键词: 乙酰六肽-8，弹性，抗衰老，头皮护理，精华 